\title{
A Study of United States Hydroelectric Plant Ownership
}

\author{
Douglas G. Hall, INL Project Manager \\ Kelly S. Reeves, NPS \\ June 2006
}

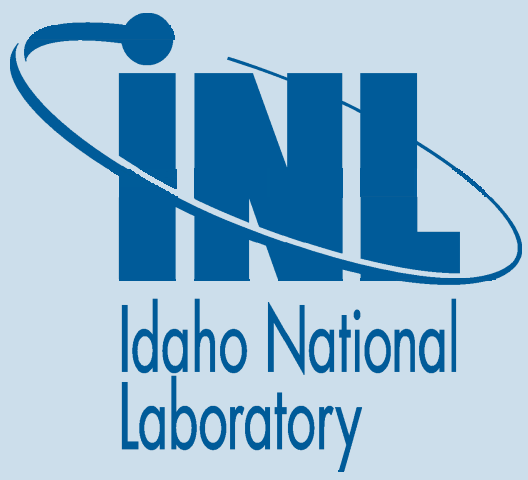

The INL is a U.S. Department of Energy National Laboratory operated by Battelle Energy Alliance 


\section{DISCLAIMER}

This information was prepared as an account of work sponsored by an agency of the U.S. Government. Neither the U.S. Government nor any agency thereof, nor any of their employees, makes any warranty, express or implied, or assumes any legal liability or responsibility for the accuracy, completeness, or usefulness of any information, apparatus, product, or process disclosed, or represents that its use would not infringe privately owned rights. References herein to any specific commercial product, process, or service by trade name, trademark, manufacturer, or otherwise, does not necessarily constitute or imply its endorsement, recommendation, or favoring by the U.S. Government or any agency thereof. The views and opinions of authors expressed herein do not necessarily state or reflect those of the U.S. Government or any agency thereof. 


\title{
A Study of United States Hydroelectric Plant Ownership
}

\author{
Douglas G. Hall, INL Project Manager \\ Kelly S. Reeves, NPS
}

June 2006

\section{Idaho National Laboratory \\ Idaho Falls, Idaho 83415}

Prepared for the

National Renewable Energy Laboratory

Tribal Energy Program

Under DOE Idaho Operations Office

Contract DE-AC07-05ID14517 



\begin{abstract}
Ownership of United States hydroelectric plants is reviewed from several perspectives. Plant owners are grouped into six owner classes as defined by the Federal Energy Regulatory Commission. The numbers of plants and the corresponding total capacity associated with each owner class are enumerated. The plant owner population is also evaluated based on the number of owners in each owner class, the number of plants owned by a single owner, and the size of plants based on capacity ranges associated with each owner class. Plant numbers and corresponding total capacity associated with owner classes in each state are evaluated. Ownership by federal agencies in terms of the number of plants owned by each agency and the corresponding total capacity is enumerated. A GIS application that is publicly available on the Internet that displays hydroelectric plants on maps and provides basic information about them is described.
\end{abstract}




\section{SUMMARY}

The objective of this study was to provide a clear understanding of U.S. hydroelectric plant ownership. Ownership was reviewed by placing plant owners in six owner classes as defined by the Federal Energy Regulatory Commission. The two principal perspectives of the review were: 1) the number of plants owned by the owners in each class and (2) the corresponding amount of total capacity associated with each owner class. These two perspectives provide significantly different views of the ownership of U.S. hydroelectric generating capability. Also of interest were the number of owners in each class and what they own both in terms of the number of plants owned by a single owner and the power class of plants owned.

Plant population and ownership patterns within each of the fifty states were reviewed both from the perspective number of plants and total capacity located in the state and the number of plants and corresponding total capacity associated with each owner class. Ownership by federal agencies was reviewed to understand what agencies own plants and the portions of the federally owned plant population and corresponding capacity owned by each agency.

The study was conducted by querying the 1998 version of the Federal Energy Regulatory Commission's Hydroelectric Resource Assessment (HPRA) database to group plants by state and owner class, which are database fields. Numbers of plants and the associated total capacity were then enumerated. National totals were obtained by summing the state totals. The database was also queried to group plants by federal agency owners allowing numbers of plants and associated total capacity to be enumerated for each agency. Some information was obtained by spreadsheet analysis of the basic plant numbers and associated capacity for each state.

The principal characteristic of U.S. hydroelectric plant ownership is the private sector (private utility and non-utility owners, cooperatives, and industrial owners) owns most of the 2,388 plants (69\%), but the public sector (federal and non-federal public owners) owns most (73\%) of the $74,872 \mathrm{MW}$ of capacity. Private owners that are not utilities own $38 \%$ of the plants corresponding to only $4 \%$ of the total capacity, while private utilities own $31 \%$ of the plants corresponding to $24 \%$ of the total capacity. Seven federal agencies own the largest fraction of the total capacity (51\%). Non-federal publicly-owned plants constitute $24 \%$ of the plant population corresponding to $22 \%$ of the total capacity.

Nearly three-quarters of the plant owners own only one plant while three federal agencies: Army Corps of Engineers, Bureau of Reclamation, and the Tennessee Valley Authority are each responsible for between 29 and 77 plants with these plants representing virtually all of the capacity owned by federal agencies. Four other federal agencies are responsible for 9 plants that have a total capacity of $223 \mathrm{MW}$ compared to the $37,215 \mathrm{MW}$ that is federally owned. All of the owner classes have low power and small hydro classes of plants except the federal owner class., which predominately owns large hydro plants. In all cases, the great majority of the total of the capacity is derived from the large hydro plants. 
The maximum number of plants in a single state are located in California (411) where the number of plants owned by the public and private sectors is approximately equal. The highest total capacity in any state is located in Washington $(22,718 \mathrm{MW})$ where nearly all of the capacity is publicly owned. Private ownership of plants is $50 \%$ or greater in 33 states. Ninety percent of the federally owned capacity is located in 13 states.

A geographic information system (GIS) application on the Internet called the Virtual Hydropower Prospector provides a means of viewing U.S. hydroelectric plants on maps and obtaining basic information about them. The application allows the user to view the plants in the context of hydrography, power and transportation infrastructure, cities and populated areas, and federal land use. In many cases, the plant name and owner information obtained from the application can be used to find additional information about the plant and its owner on the Internet.

There is a significant difference between who owns a majority of U.S. hydroelectric plants (the private sector) and who owns a majority of the U.S. hydroelectric capacity (the public sector with a majority being federally owned). There is a disparity between the number of non utility private owners which make up about $60 \%$ of the owners and the amount of capacity they own, which is only $4 \%$ of the total U.S. hydroelectric capacity. Given the unlikelihood of the development of large hydropower projects in the present U.S. environment, hydroelectric growth is dependent upon the development of distributed generation using low power and small hydro class plants. For significant growth to occur, there will have to be a dramatic increase in the number of these plants and probably an accompanying increase in the number of plant owners. Most states already have significant numbers of these classes of plants indicating that the hydroelectric industry has the experience necessary for further expansion in a favorable economic climate. It is noted that federal ownership of approximately half of the U.S. hydroelectric capacity is unusual in the U.S. commercial power industry and is an artifact of federal power infrastructure development during the first half of the last century.

For further information or comments, please contact:

Douglas G. Hall, Program Manager

INL Hydropower Program

Idaho National Laboratory

P.O. Box 1625, MS 3830

Idaho Falls, ID 83415-3830

Phone: (208) 526-9525

E-mail:douglas.hall@inl.gov 


\section{ACKNOWLEDGMENTS}

The authors express their appreciation of Roger Taylor of the NREL Tribal Energy Program for sponsoring this study. They also express their thanks to Bob Neilson, INL Renewable Energy and Power Department manager and Peggy

Brookshier of the DOE-ID operations office for their reviews and comments on this report. 


\section{CONTENTS}

ABSTRACT

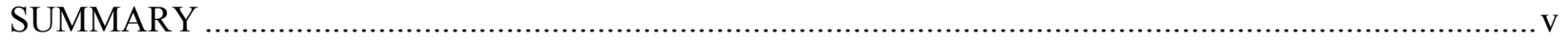

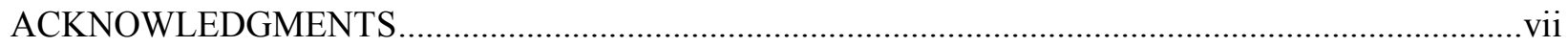

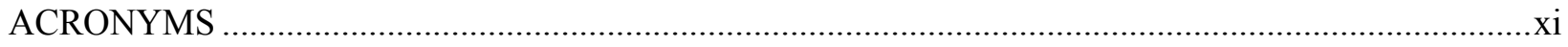

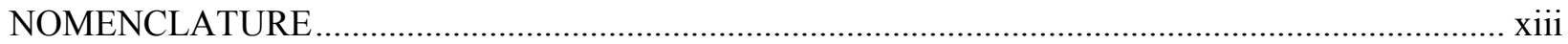

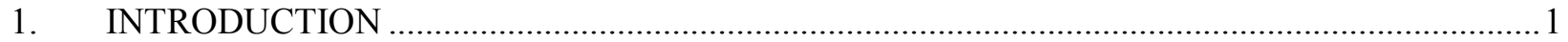

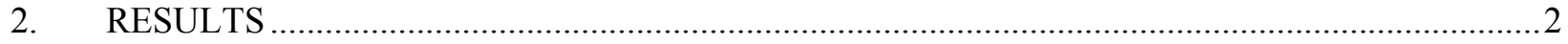

2.1 Hydroelectric Plant Ownership by Owner Class ...........................................................

2.2 Classes of Plants Owned by Owner Class .........................................................................

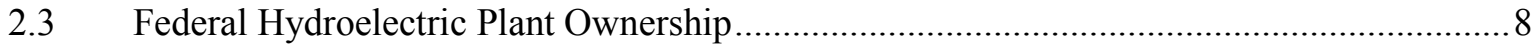

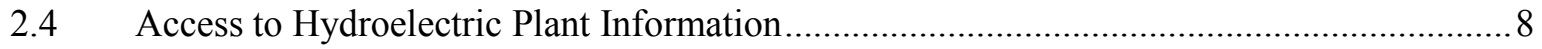

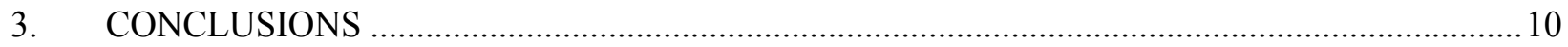

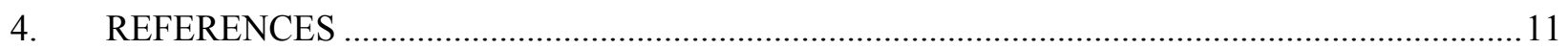

FIGURES

Figure 1. Distribution of U.S. hydroelectric plants by owner class in terms of (a) number and (b) total owner class capacity.

Figure 2. Number of U.S. hydroelectric plant owners in each of six owner classes............................... 3

Figure 3. Number of owners owning various numbers of U.S. hydroelectric plants. .............................. 3

Figure 4. Distribution of U.S. hydroelectric plants by power class in terms of (a) number and (b) total power class capacity.

Figure 5. Power class distribution in terms of number of U.S. hydroelectric plants for each owner class.

Figure 6. Power class distribution in terms of total power class capacity of U.S. hydroelectric plants for each owner class.

Figure 7. Number of U.S. hydroelectric plants in each of the six owner classes by state........................ 6

Figure 8. Total capacity of U.S. hydroelectric plants in each of the six owner classes by state ..... .7 
Figure 9. Distribution of U.S. hydroelectric plants in the federal owner class in terms of (a) number and (b) total agency owned capacity.

Figure 10. Desktop of the Virtual Hydropower Prospect GIS application showing its areas for functions and display control and map and information display. 


\section{ACRONYMS}

DOE U.S. Department of Energy

FERC Federal Energy Regulatory Commission

GIS geographic information system

A set of digital geographic information, such as map layers and elevation data layers, which can be analyzed using both standardized data queries as well as spatial query techniques.

HPRA Hydroelectric Power Resources Assessment

INL Idaho National Laboratory

NREL National Renewable Energy Laboratory

NPS Nuclear Placement Services

VHP Virtual Hydropower Prospector

A GIS application on the Internet that displays hydroelectric plants on hydrologic region maps and provides basic information about them. 


\section{NOMENCLATURE}

Capacity

Plant owner

Plant owner class presence

Plant power class
Typically refers to the design power rating of a hydroelectric plant and are denoted by units of "MW".

The individual, company, municipality, non-federal public agency, or cooperative owning a hydroelectric plant or in the case of federal agencies, responsible for the administration, operation, and maintenance of a hydroelectric plant.

Used to count the number of owner classes a particular owner is listed in. For example, a private non-utility owner may own one or more plants producing electricity for non-industrial dedicated use or sale and also own one or more plants producing electricity for dedicated industrial use. In this case the owner have an owner class presence of two.

- Large hydro - capacity $>30 \mathrm{MW}$

- Small hydro - capacity $>1 \mathrm{MW}$ and $\leq 30 \mathrm{MW}$

- Low power - capacity $<1 \mathrm{MW}$. 


\section{A Study of United States Hydroelectric Plant Ownership \\ 1. INTRODUCTION}

The United States hydroelectric plant population is comprised of 2,388 licensed plants (not including pumped storage plants) according to the 1998 version Federal Energy Regulatory Commission's Hydroelectric Resource Assessment (HPRA) database (FERC 1998), which was the version available to the authors at the time of this study. These plants range in capacity from less than $100 \mathrm{~kW}$ to over $6,000 \mathrm{MW}$ and have a total capacity of $74,872 \mathrm{MW}$. The plants are owned by 1,134 owners which include owners in the public and private sectors. The private sector owners include: private utilities, individuals and private companies, cooperatives, and industrial owners. The public sector owners include municipalities and other non-federal public agencies, and several federal agencies.

The objective of the study was to review and characterize U.S. hydroelectric plant ownership both nationally and in each of the 50 states. Ownership by plant owners in each of the six private and public owner classes was viewed from two principal perspectives: a) number of plants in an owner class and b) total amount of capacity associated with each owner class. ${ }^{a}$ These two perspectives provide very different views of the ownership of U.S. hydroelectric generating capability. Also of interest was the number of plants owned by individual owners and the power class of plants associated with each owner class. Plant ownership by federal agencies was a particular focus of the study.

The study was conducted by querying the HPRA database to group plants by state and owner class, which are database fields. Numbers of plants associated with each owner class and the associated total capacity were then enumerated. National totals were obtained by summing the state totals. The database was also queried to group plants by federal agency owners allowing numbers of plants and associated total capacity to be enumerated for each agency. Some information was obtained by spreadsheet analysis of the basic plant numbers and associated capacity for each state.

The results of the study are presented in the next section followed by a section that presents conclusions based on the ownership characteristics. No discussion of technical approach is provided because of its relative simplicity as described in the preceding paragraph.

\footnotetext{
${ }^{a}$ Throughout this report, statements of the number of plants or the total capacity of a group of plants "associated with" an owner class means the number of plants or the total capacity of these plants owned by owners in an owner class.
} 


\section{RESULTS}

\subsection{Hydroelectric Plant Ownership by Owner Class}

The Federal Energy Regulatory Commission groups hydroelectric plant owners into six classes:

- Municipal and other non-federal public

- Private utility

- Private non-utility

- Industrial

- Federal

- Cooperative.

The owners of the 2,388 licensed U.S. hydroelectric plants are assigned to one or more of these six owner classes. The distribution of the number of hydroelectric plants associated with each of these owner classes is shown in Figure 1. The figure also shows the amount of capacity and the fraction of the total U.S. hydroelectric capacity of $74,872 \mathrm{MW}$ associated

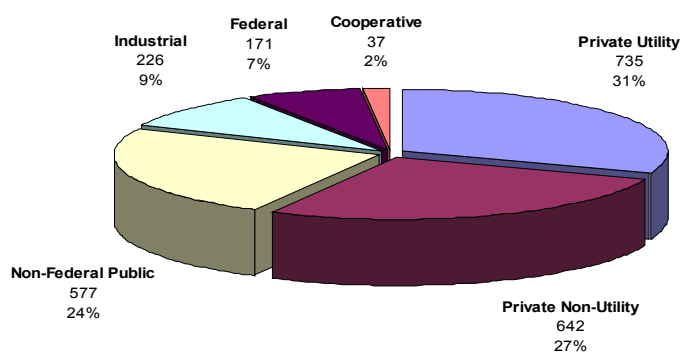

Total Number of Plants: $\quad \mathbf{2 , 3 8 8}$

(a) with each owner class.

Figure 1 shows that while over two-thirds $(69 \%)$ the plants are owned by private owners (private utility $-31 \%$, private non-utility $-27 \%$, and industrial $-9 \%$, cooperative $-2 \%$ ), nearly three-quarters of the total capacity is owned by federal and non-federal public owners (federal $51 \%$ and non-federal public $-22 \%$ ).

The number of owners in each owner class is shown in Figure 2. Different federal agencies are considered to be different owners. Since an owner may own plants in more than one owner class (e.g., private non-utility and industrial) the total number in Figure 2 is referred to as "presence" rather than owners. The total number of individual owners is 1,134 , while the total number of presences is 1,152 . As with the distribution of the plant population by owner class, the distribution of the plant ownership shows that approximately $70 \%$ of the plant ownership is in the private sector.

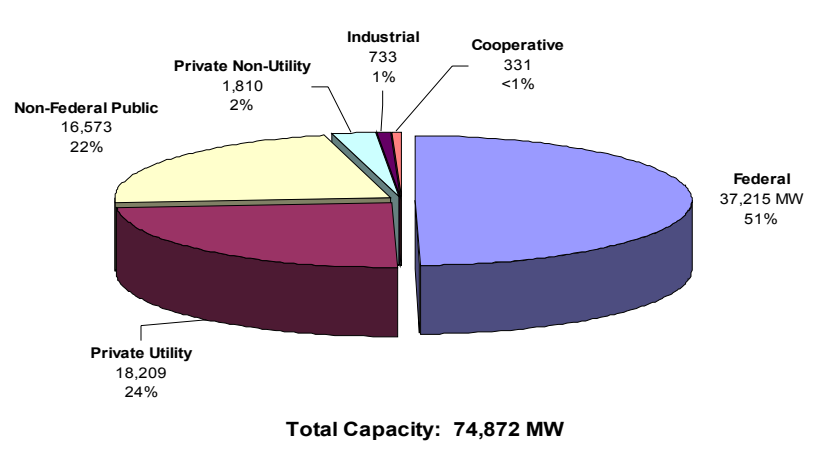

(b)

Figure 1. Distribution of U.S. hydroelectric plants by owner class in terms of (a) number and (b) total owner class capacity. 


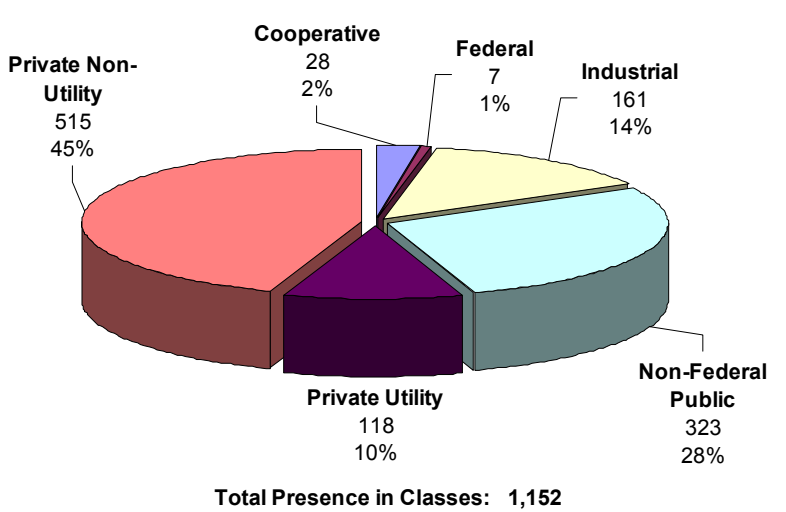

Figure 2. Number of U.S. hydroelectric plant owners in each of six owner classes.

A revealing view of U.S. hydroelectric plant ownership is provided by the number of plants owned by individual owners. Figure 3 shows the number of owners that own a specified number of plants. This figure shows that nearly three-quarters of the owner population own only one plant. At the other extreme, there are 10 owners who own 20 or more plants with 77 being the highest number of plants owned by a single owner.

\subsection{Classes of Plants Owned by Owner Class}

One view of plant ownership is what power class of plants is associated with a particular owner class. For this view, plants have been divided into the following power classes:

- Large hydro - capacity > $30 \mathrm{MW}$

- $\quad$ Small hydro - capacity $>1 \mathrm{MW}$ and $\leq$ $30 \mathrm{MW}$

- Low power - capacity $<1 \mathrm{MW}$.

The distribution of the U.S. hydroelectric plant population by power class is shown in Figure 4. A large majority of the plant

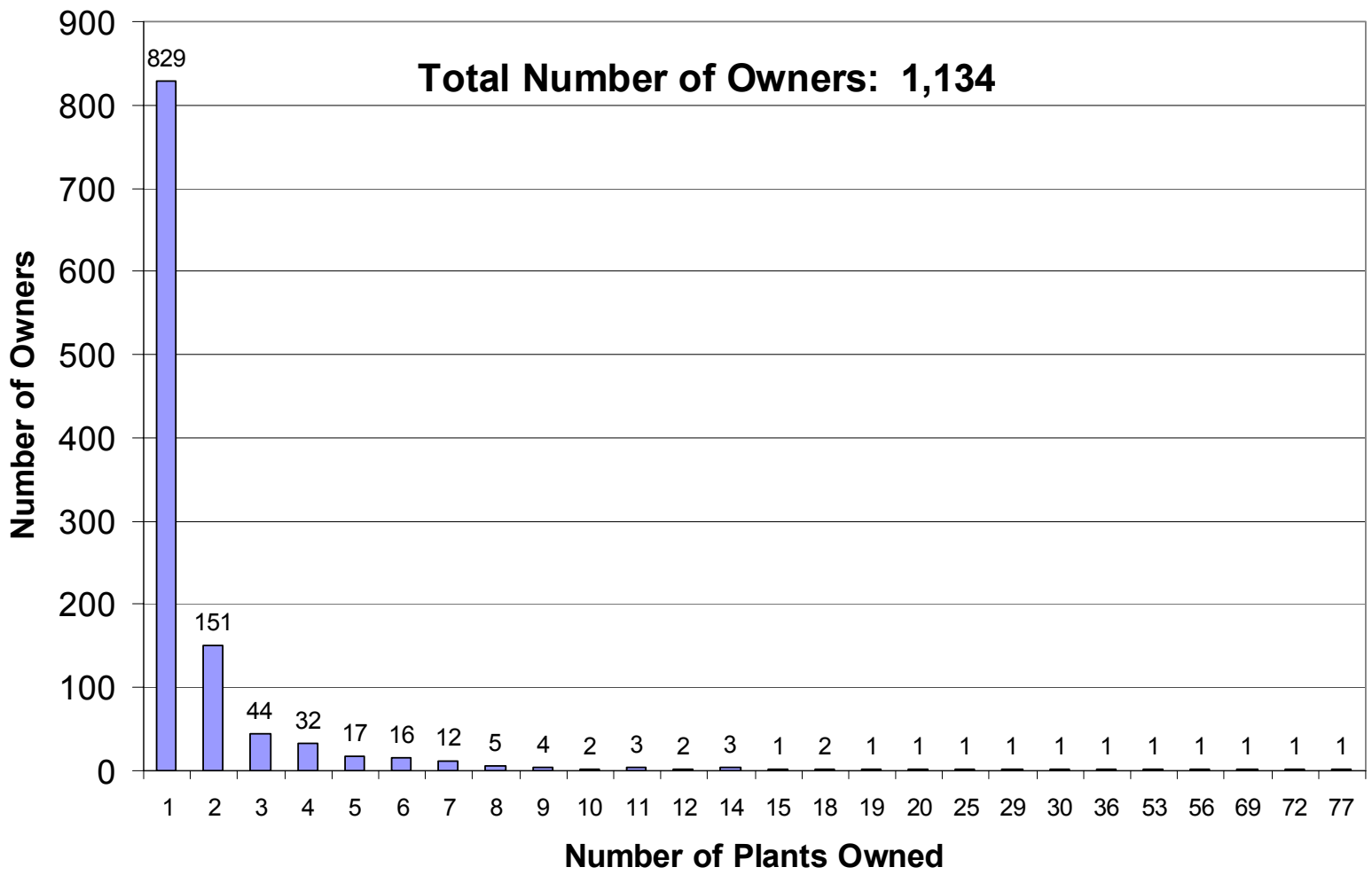

Figure 3. Number of owners owning various numbers of U.S. hydroelectric plants. 


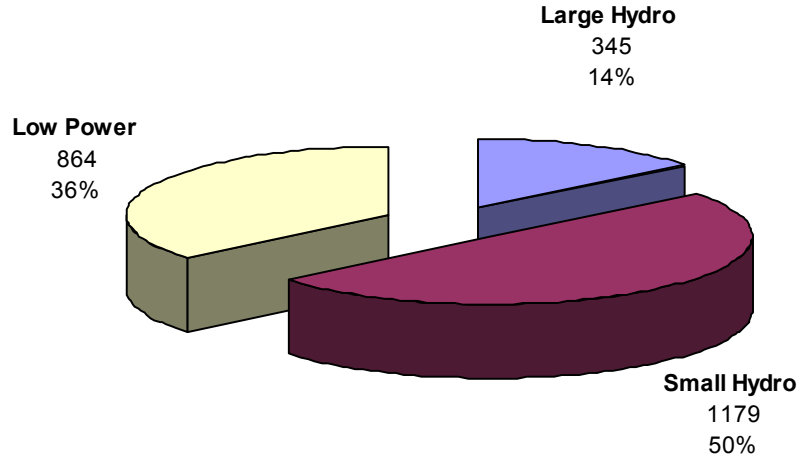

Total Number of Plants 2,388

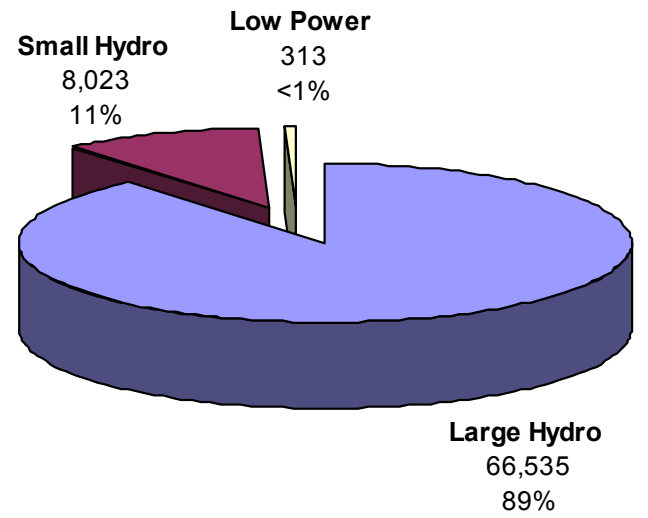

Total Capacity: 74,872 MW

(b)

Figure 4. Distribution of U.S. hydroelectric plants by power class in terms of (a) number and (b) total power class capacity.

population ( $86 \%)$ are low power or small hydro classes of plants; that is, have capacities less than 30MW. In contrast, the figure also shows that the remaining $14 \%$ of the plants that are in the large hydro class possess a large majority of the capacity $(89 \%)$

The number of plants in each power class associated with each of the six owner classes is shown in Figure 5. Owners in the private nonutility, non-federal public, and industrial owner classes for the most part own low power and small hydro plants. Private utilities and cooperatives own predominately small hydro plants, while most of the plants owned by federal agencies are large hydro plants. This view changes somewhat when viewed from the amount of capacity corresponding to the plants in each power class associated with each owner class as shown in Figure 6. This figure shows that while a majority of the plants owned by owners in the private utility and non-federal public owner classes are small hydro plants, most of the capacity owned by these classes of owners is derived from the relatively small number of large hydro plants they own which is also the case for the other owner classes.

The distribution of the number of plants associated with each of the six owner classes by state is shown in Figure 7. The largest number of plants in a single state are located in California (411) where the largest number of plants are associated with the non-federal public owner class. In 33 states $50 \%$ or more of the plants are owned by owners in the private sector. All the plants in Hawaii, Maryland, and Louisiana are privately owned. Eighty percent $(80 \%)$ of the 171 federally owned plants are located in 13 states with Tennessee having the largest number (26).

The counterpart to Figure 7 is the total capacity associated with the six owner classes in each state, which is shown in Figure 8. This view provides a very different picture from the one oriented towards numbers of plants. 


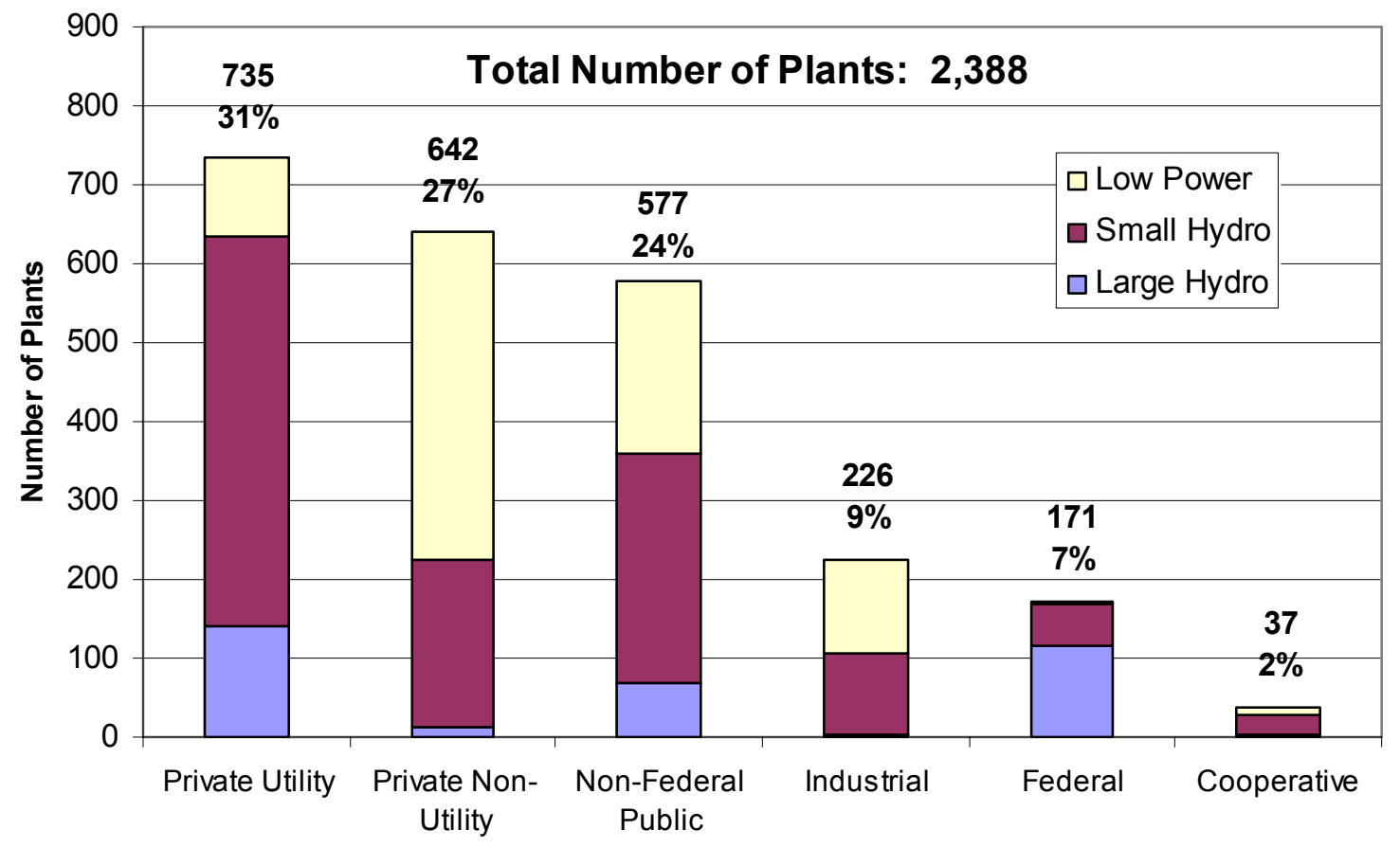

Owner Class

Figure 5. Power class distribution in terms of number of U.S. hydroelectric plants for each owner class.

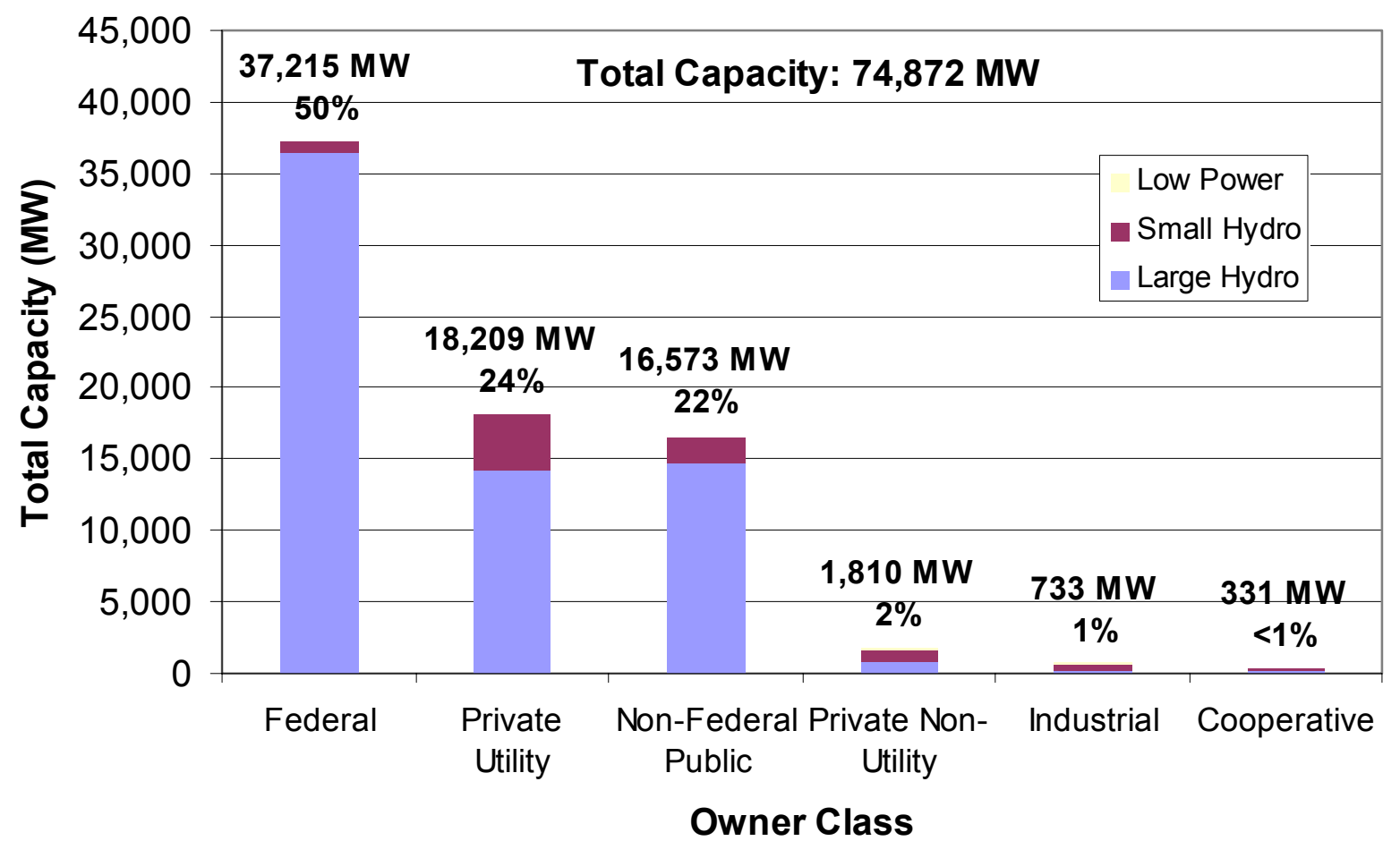

Figure 6. Power class distribution in terms of total power class capacity of U.S. hydroelectric plants for each owner class. 


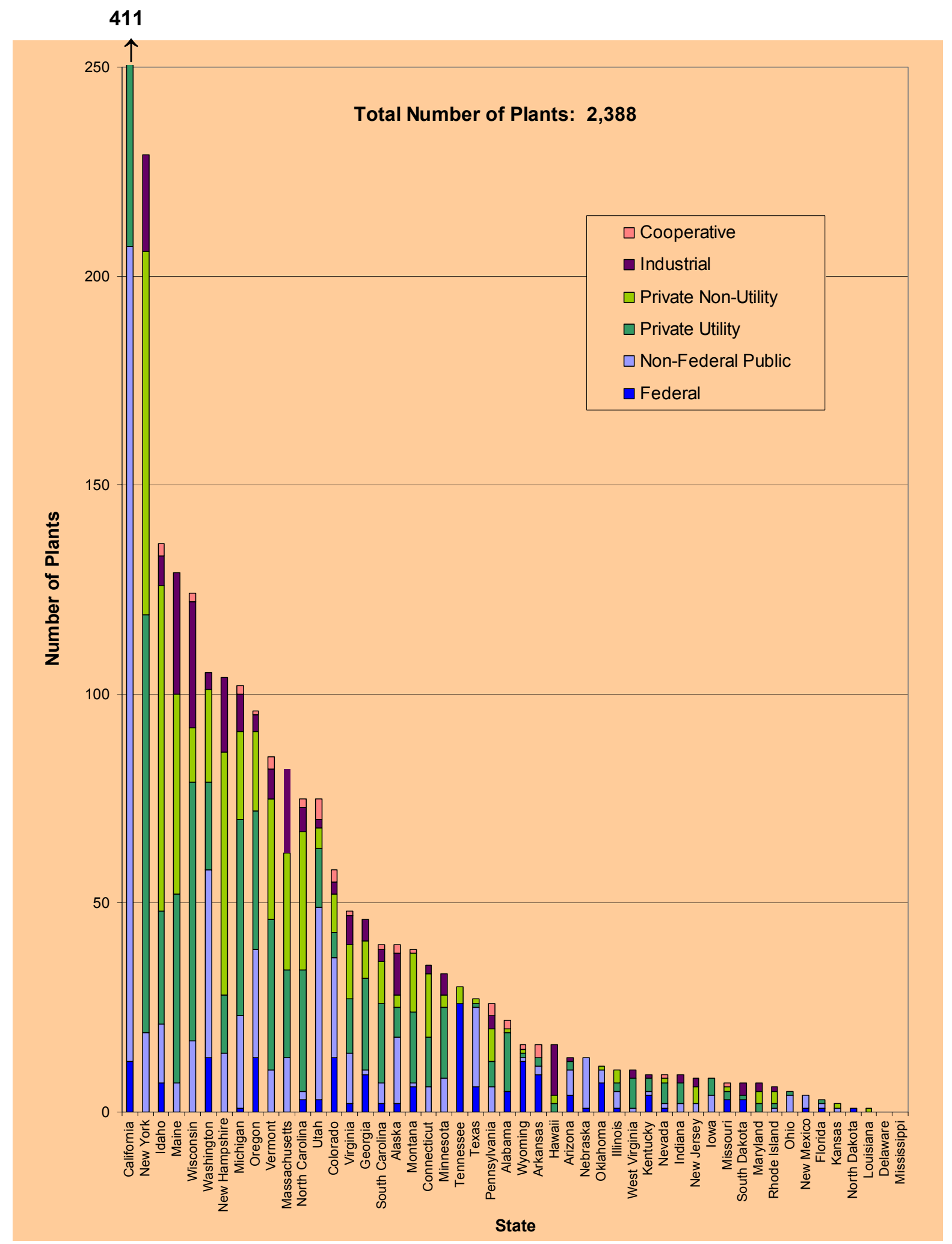

Figure 7. Number of U.S. hydroelectric plants in each of the six owner classes by state. 


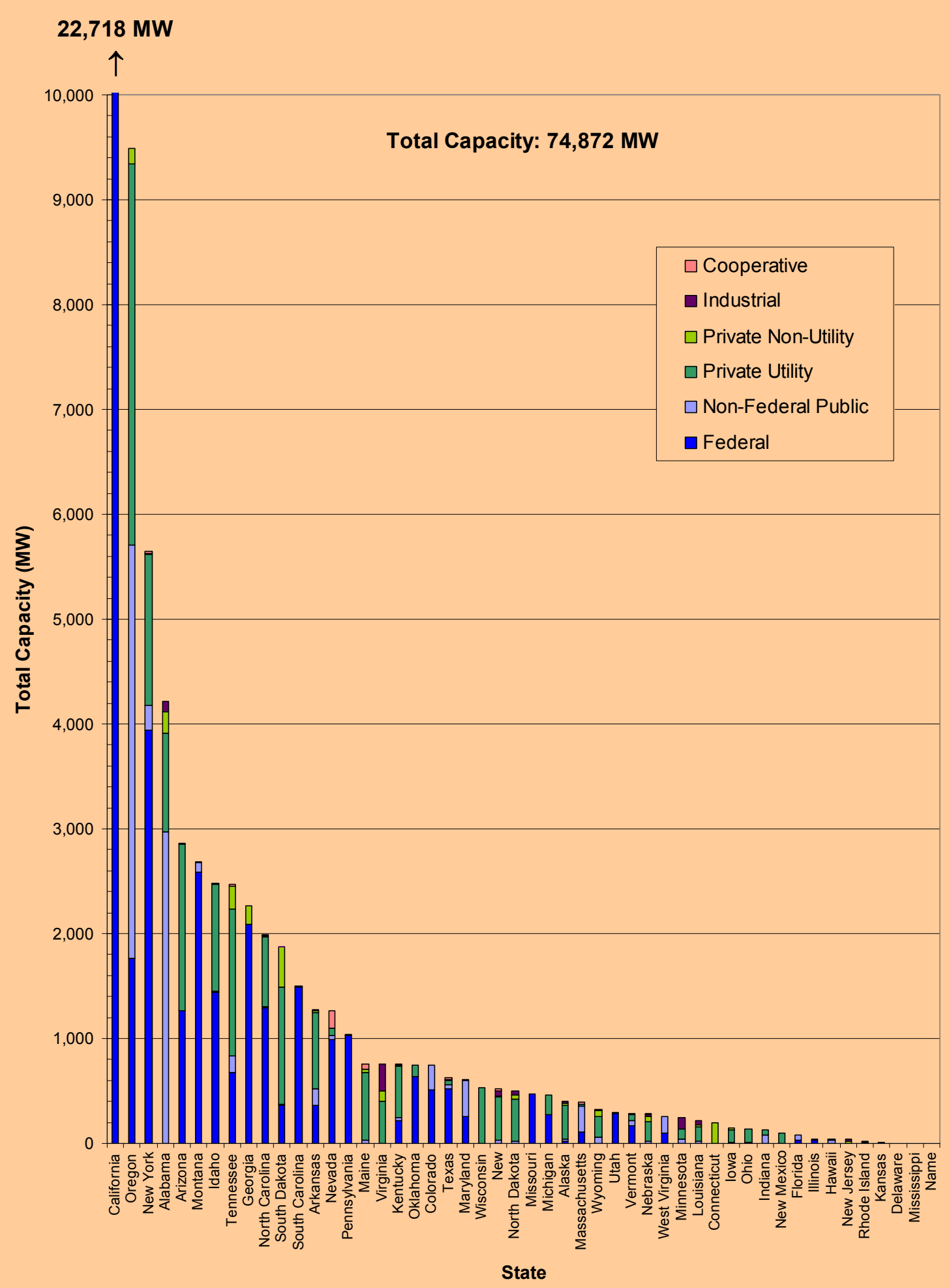

Figure 8. Total capacity of U.S. hydroelectric plants in each of the six owner classes by state . 
Thirty percent $(30 \%)$ of the national hydroelectric plant capacity is located in one state - Washington. The vast majority of this capacity is owned by federal and non-federal public agencies. In the four states in which the highest amount of capacity is located:

Washington, California, Oregon, and New York, most of the capacity is owned by public owners. In eight states: Arizona, Tennessee, South Dakota, Nevada, Kentucky, Colorado, North Dakota, and Wyoming more that $80 \%$ of the capacity is owned by federal agencies.

\subsection{Federal Hydroelectric Plant Ownership}

Seven federal agencies own 171 hydroelectric plants in the U.S. These plants have a total capacity of $37,215 \mathrm{MW}$ or $50 \%$ of the total U.S. hydroelectric capacity. The federal agencies owning plants in descending order of the number of plants owned are:

- Army Corps of Engineers

- Bureau of Reclamation

- Tennessee Valley Authority

- Bureau of Indian Affairs

- Alaska Power Administration ${ }^{\mathrm{b}}$

- International Boundary and Water Commission

- Restoration Hydroelectric Limited.

The distribution of ownership in terms of the number of plants owned and the corresponding total capacity is shown in Figure 9 The Army Corps of Engineers and the Bureau of Reclamation own $78 \%$ of the federally owned plants corresponding to $91 \%$ of the federally owned capacity.

\footnotetext{
${ }^{\mathrm{b}}$ The Alaska Power Administration is listed because the study was performed using the 1998 version of the HPRA database. This organization no longer exits.
}

\subsection{Access to Hydroelectric Plant Information}

The locations of individual plants and information about them including: plant name, owner's name, and capacity are available using a GIS application on the Internet called the Virtual Hydropower Prospector (VHP). The application is accessible at:

http://hydropower.inl.gov/prospector/ and does not require any special software or licenses for use. In addition to displaying hydroelectric plants on maps of the 20 U.S. hydrologic regions, the application also displays context features including:

- Hydrography

- Power system (hydroelectric plants, other power plants, transmission lines, and substations)

- Transportation (roads and railroads)

- Areas and places (city centers; populated areas; county, state, and hydrologic region boundaries)

- Land Use (exclusion zones based on federal and statutes and policies and environmental sensitivities; and land that is the purview of federal agencies including: Bureau of Indian Affairs, Bureau of Land Management, Bureau of Reclamation, Department of Defense, U.S. Forest Service, U.S. Fish \& Wildlife Service, U.S. Park Service).

In addition to displaying these features on the map, attribute information about them is also provided by the application. The VHP desktop displaying a map of the Pacific Northwest Region is shown in Figure 10.

Particularly for large plants and owners, more extensive information about a specific hydroelectric plant can often be obtained on the Internet using the name of the plant or the owner provided by the VHP application. 


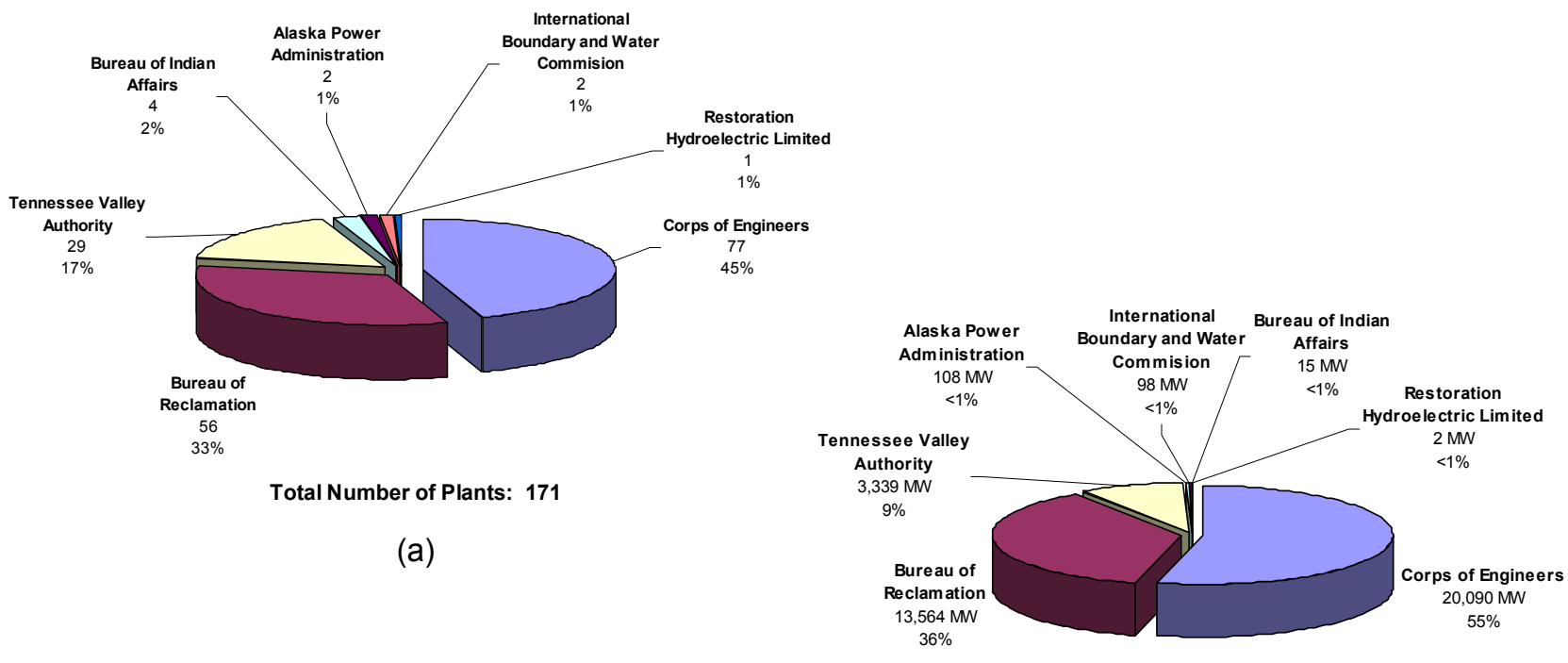

Total Capacity: 37,215 MW

(b)

Figure 9. Distribution of U.S. hydroelectric plants in the federal owner class in terms of (a) number and (b) total agency owned capacity.

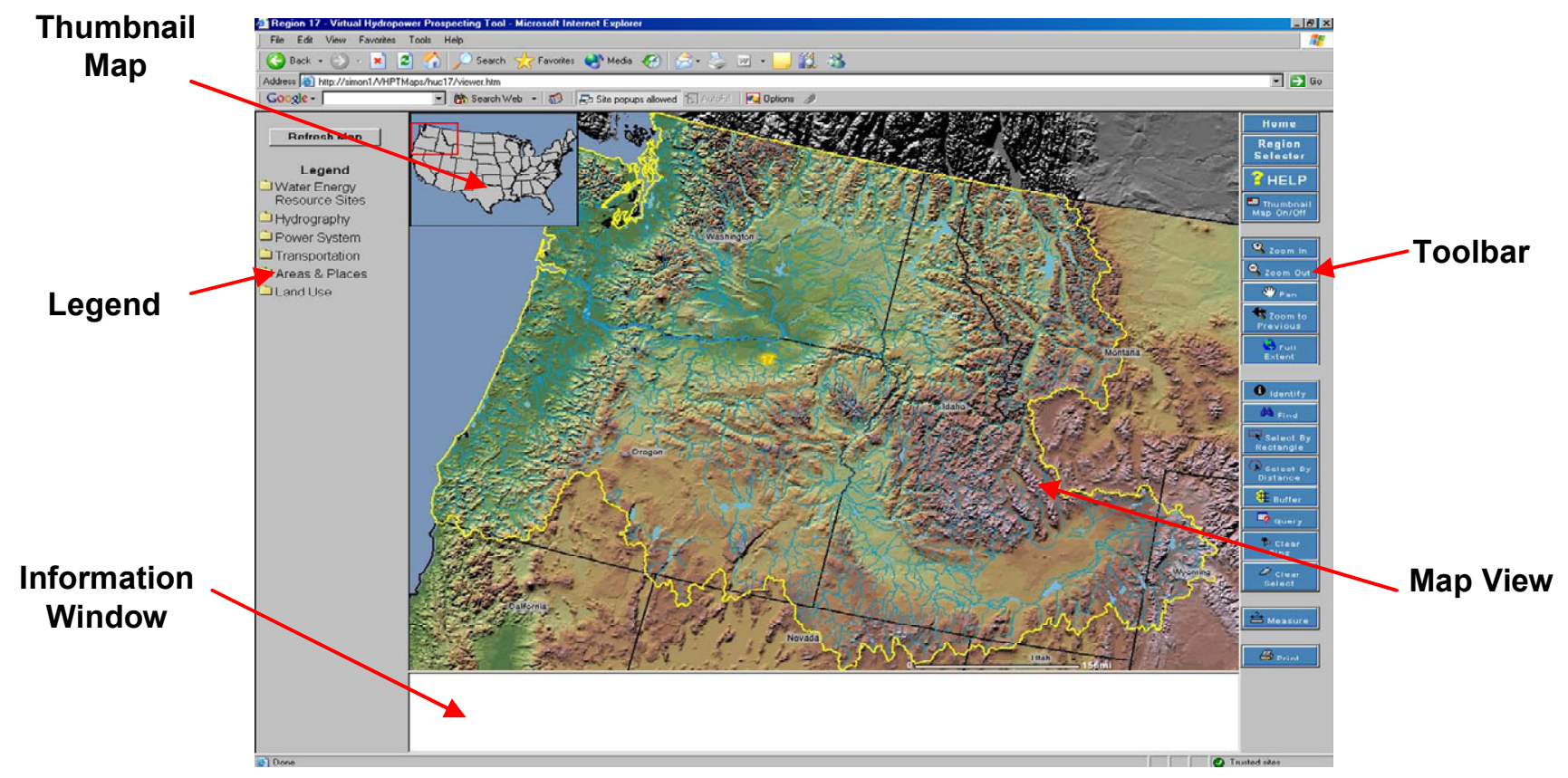

Figure 10. Desktop of the Virtual Hydropower Prospect GIS application showing its areas for functions and display control and map and information display. 


\section{CONCLUSIONS}

Hydroelectric plant ownership in the United States is predominately in hands of the private sector $(69 \%)$. On the other hand, capacity is predominately owned by federal and non-federal public owners $(75 \%)$. Private non-utility ownerships are the largest percentage of plant ownerships (45\%) indicating a significant presence of individuals and non-utility companies in the plant ownership population. If cooperative and industrial ownerships are included (which results in a small amount of double counting of owners), the percentage of ownership by private individuals and non-utility companies jumps to approximately $60 \%$, but these owners own less that $4 \%$ of the total capacity.

Nearly $75 \%$ of the plant owners own only one plant. At the other extreme, there are a small number of owners (10) who own 20 or more plants, and 24 owners who own 10 or more plants. The Army Corps of Engineers, Bureau of Reclamation, and Tennessee Valley Authority are three of the owners owning more than 20 plants each. Owners in the private non-utility, nonfederal public, and industrial owner classes predominately own low power or small hydro plants. Owners in the private utility and cooperative owner classes own mostly small hydro plants, while federal class owners own predominately large hydro plants. In all cases, the predominate amount of capacity comes from the large hydro plants associated with each owner class.

The numbers indicate that to date, the vast majority of U.S. hydroelectric capacity is owned by federal, non-federal public, and private utility owners, which are the classes in which owners can make large capital investments. In the present environment, the development of new large hydro projects in the U.S. seems unlikely. The implication is that if there are going to be significant increases in hydro electric capacity in the future, the number of low power and small hydro plants and probably plant owners will have to grow dramatically, since these classes of plants currently contribute slightly more than $10 \%$ to the total U.S. hydroelectric capacity. A positive indicator that this is possible from the study results is that $86 \%$ of the plants in the U.S. hydroelectric plant population are low power and small hydro plants. This indicates that the industry has the experience to implement distributed generation using a large number of plants.

The spatial view of the U.S. hydroelectric plants and plant ownership shows that in terms of the number of plants, California is the hydropower capital of the nation, but from the amount of capacity, Washington is the hydropower capital of the nation. In 33 states more than half of the plants are owned by owners in the private sector indicating a wide spatial distribution of private plant ownership. In contract, $90 \%$ of the capacity of the federally owned capacity is located in 13 states; most located in the western or East coast states.

Slightly over $50 \%$ of the nation's hydroelectric capacity is federally owned. Of this federally owned capacity, virtually all of it is owned by three federal agencies: Army Corps of Engineers, Bureau of Reclamation, and the Tennessee Valley Authority. This level of federal ownership is unusual in the U.S. commercial power industry and is an artifact of federal power infrastructure development during the first half of the last century. 


\section{REFERENCES}

Federal Energy Regulatory Commission, 1998,

Hydroelectric Power Resources Assessment (HPRA) Database, 1998. 